\title{
Other worlds and sexualisation
}

In contrast to detachment engagement transitions, the musical events in this chapter reveal ways in which gender and other social boundaries were negotiated in situations of intensified musical physicality (Cowan 1990; McIntosh 2010). More specifically, the other worlds and sexualisation forms of musical physicalisation that variously arose and merged in Yogyakarta's kampung and commercial-venue events challenge conventional understandings of Javanese power. These physicalisations, I argue, shine light on the relationships between musical performance, gendered bodies and the social dynamics characteristic of downtown Yogyakarta in the early post-Soeharto years.

KAMPUNG JATILAN AND KRIDOSONO METAL/ELECTRONIC

'Other worlds' refers to the highly physicalised dance and/or related bodily movements that reflect an actor's entrance into an alternative reality or state of being. While political campaigns in early post-Soeharto Yogyakarta sometimes included menacing other worlds-style hysteria, the more popular and widespread cases derived primarily from Javanese mysticism and western-influenced metal and electronic musics. This section seeks to demonstrate how these latter cases produced outlets of expression that helped to transcend performer/audience and gender-based social divisions, which in turn influenced and were influenced by the gendered habitus in daily life.

Of the numerous indigenist and regionalist performance types that have long challenged stereotypes of conservatism in Java (Richter 2008a:180, note 6), in 2001 the jatilan trance dance was immensely popular. ${ }^{1}$ Jatilan is generally performed in a cordonedoff arena, within which the dancers enter into a trance, as reflected in performers' trance-like or possessed movements and facial expressions. M. Wienarti (1968) has discussed jatilan and its animist

1 On the related jaranan trance dance popular in East Java, see Clara van Groenendael 2008. 
associations, as well as its historical function in rites of passage such as marriage. Margaret Kartomi (1973) has explored 'folk trance art forms' more broadly in terms of their pre-Hindu origins and contemporary entertainment functions. I found the performances noteworthy for the way in which the trance phases signalled the submergence of performers into an 'other world', and also because audiences consisted of women, men and children.

The first jatilan I witnessed took place late at night in a village north of Yogyakarta, where two rows of four men in matching red costumes and make-up and holding a hobbyhorse lined up, and then began stepping delicately in formation as the music built up in tempo and volume. Within minutes some of the dancers' eyes began to roll, and soon after that mayhem broke out with whip cracking, flame swallowing, and much frenzied running and hopping about, all to great shrieks and laughter among the 200-strong audience. I also watched a number of jatilan events in urban kampung. These took place in the middle of the day, generally around Independence Day, with audiences comprised largely of mothers with young children and young men with dyed hair and other signs of western punk and grunge affiliation. Also in contrast to the village jatilan, where the build-up to the trance was more gradual, in the urban cases all of the dancers simultaneously fell into a violent heap and, upon rising to their feet, began trance dancing together.

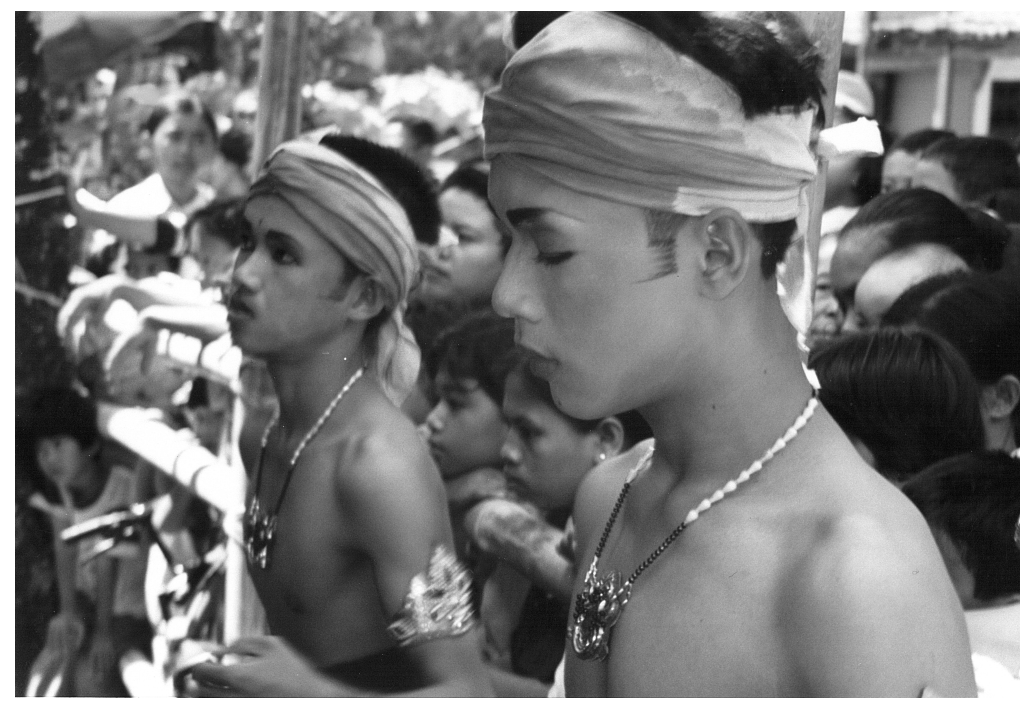

Jatilan dancers in an urban kampung 


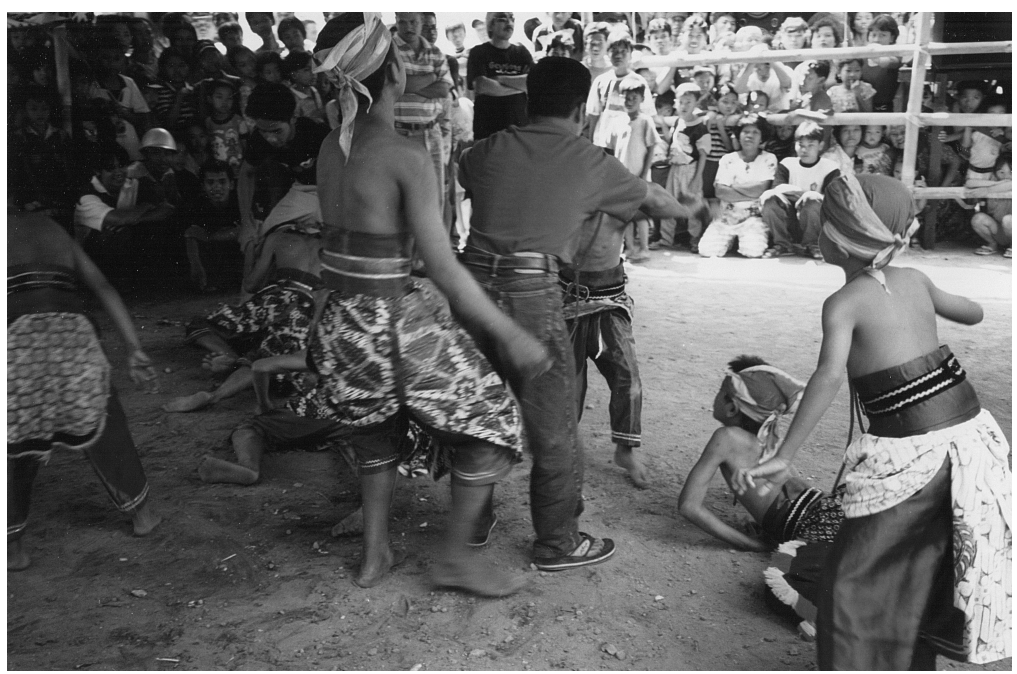

Jatilan dancers in an urban kampung

Kampung jatilan performances allowed onlookers to view familiar neighbours entering into an unfamiliar, other world of trance. Audiences remained physically immobile and separate from (though in thrilling proximity to) the performers, except for the occasional audience member who, entranced, entered the arena. In turn, performer actions on centre stage can be related to gender roles and relations. The shaman (dukun), always a male, along with the deep gong players wielded the transformative power needed to transport the dancers to the other world. The shaman's movements were poised and deliberate, while those of the trance dancers were its unpredictable and unwieldy opposite. These roles in turn can be related to factors of gender, physicality, and power. The 'feminised' appearance and movements of the dancers can be seen to draw on ideas about the subordinate 'irrational' female, something Norma Sullivan (1994:170) points out in her discussion of communal rituals. By contrast, the poised and deliberate moves of the shaman may be seen as masculine and potent (Errington 1990:41-2).

In contrast to the jatilan trance dances, many western scholars associate 'underground', 'punk', 'black metal' and related genres at the more abrasive end of Indonesia's pop-rock spectrum with symbolic protest, self-expression, and democratic progressiveness (Baulch 2007; Bodden 2005; Hill and Sen 2000). The following 
performances fit broadly within this cluster of genres, but I view these within the specific context of other world physicalisations that occurred at Kridosono sports hall. This was a popular venue for events involving the chiefly youth-oriented hard rock and 'electronic' musical worlds or subcultures, and which in many cases relied on the organizational skills and networks of the ethnic-Chinese rock legend Log Zhelebour. Kridosono events were commercial in the sense that they included admission charges and involved prominent sponsor signage, although in practice they foremost created situations in which performers, and to varying degrees audiences enacted other world physicalisations to express themselves and release tensions.

For example, contestants in a 'Twelve best student bands in Central Java' competition at Kridosono included a teenage-girl dance troupe, who alternated between precise but mechanical cheer-squad movements, and looser, highly sexualised hip swivelling; and No Rain, a smartly dressed group featuring wall of sound effects reminiscent of British post-new wave groups. The attentive but largely placid and immobile crowd receiving these acts soon erupted when 'grindcore' group Radikal Corps appeared and a sizeable black-clothed sector of the audience ran to the stage. As band members pounced and growled around the stage, their fans before them broke into tortured dance moves, some casting their knees into the air while marching in circles, some pounding their upper bodies back and forth in a haze of hair, and others clasped onto the stage fence and imitated thumping their heads against a wall. Later, guest stars BIP, containing three former members of Slank, transformed the hall into an arena full of dancing women and men. Most people in the audience variously swung their heads, arms and/or whole bodies to the music and the rock stars performing on stage.

The third annual ParkinSound Performance also included widely participatory other worlds dancing at Kridosono. The audience steadily increased through the afternoon, by ten o'clock in the evening numbering well over a thousand. Many were university students and their friends, including many visitors from Jakarta. The average age was around 20 years, with many dressed self-consciously in secondhand or homemade clothing; and almost half was female, an unusually high proportion for evening public entertainment in Yogyakarta City. The most outstanding feature in common among the 18 bands was that, unlike most techno music and performance in the West, here the practices of sampling, drum machines and DJ scratching were in almost all cases combined with musicians playing standard pop/rock instruments. 
While the generally subtle and expressionistic musings of several of the groups received appreciative applause and gentle swaying from among the audience, the appearance of 'Teknoshit' heralded a phase of overtly political messages and anguished onstage other world physicalisations. Following them, Marzuki the organizer urged the audience to get up from their seats, prompting hundreds to descend from the stadium seating to the floor and dance to the pumping beat. Soon practically everyone in the hall, including young women in red and other brightly coloured jilbab (Muslim headscarves), was now dancing. Covering the floor from one end of the hall to the other, the dancers threw their arms high into the air and stepped in time to the pounding beat while facing the stage, swinging their heads from side to side for half an hour.

At Kridosono sports hall, the vast majority of those involved were lower middle- to middle-class youth and young adults. Although the performance stages were largely separate from audiences, audience physicalisation at times blended with that of the performers. For most, the thundering volume and bass rhythm induced some form of physical movement, even if at times being involuntary or only semiconscious. At a minimum, this might involve perching forward or head nodding. When physicalisation became more extreme, performer and audience actions did not manifest themselves in sexual display, but instead demonstrated socio-political expression through exhibiting a kind of bodily anguish. Kampung jatilan performances on the other hand induced thrilled giggles and gasps from the audience, especially from women and children. Despite differences of age, spatial arrangement and musical genre, both forms of other world physicalisation were highly animated, and at the same time often played down rather than accentuated gender differences and sexuality.

According to the 'traditional' idea of power in Javanese society, immobility reflects and conveys power while high levels of physical movement do not. I am arguing that the musical performances under analysis here help to problematise overly simplistic readings of the relations between gender, physicality, and power in Java. This has been demonstrated through the animation and empowerment of women in detachment engagement musical situations, in the relatively gender-neutral jatilan performances, and among youth at other world commercial-venue events. In the following sections I discuss cases involving musical sexualisation, and explore further the relationships between music, physical mobility, gender relations, and social stature. The first of these focuses on a small number of musical events that took place in kampung, and which highlight interrelationships between the three physicalisations and the main groups and genres under study in this book. 
Among the several kampung events I witnessed in Yogyakarta in 2001, the performance of campursari/dangdut crossovers was an especially prominent feature (see also Mrázek 1999:53-4). This in turn reflected and reinforced other world/sexualisation tensions and accommodations. By contrast, rock bands and their jalanan counterparts at kampung events tended to be loud, inducing physical detachment, and perhaps internal appreciation, among audiences. As I will show, a performance in the Kusuman kampung traversed all of these genres, and highlighted roles played by lead female performers and (generally all-male) musical groups in steering the proceedings and overall musical experience for all participants.

Campursaridangdut/other worlds-sexualisation transitions occurred at a village reception for a boy's circumcision that I attended with Pak Harno, a becak driver and leader of the Sosro Bahu association addressed earlier. On this occasion, the musical performance gave rise to intergenerational sexual and other tensions and accommodations between men. Before the orchestra began, five pesinden (female singers) gathered from different directions to settle at a table to the side of the performance clearing. The 200 village men there all sat chatting before the performance area in their shimmering batik shirts with stovepipe pants. The campursari music began a little after eight $\mathrm{pm}$, and moved through its characteristic tempo changes and gradual increases in volume, with the sounds blending Javanese gongs and deep percussion with synthesiser

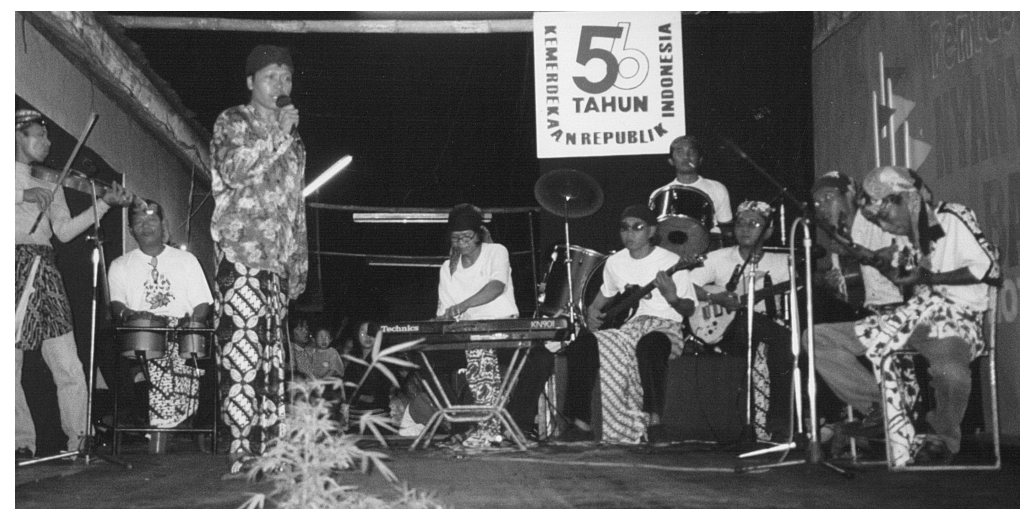

Genre-bending kampung performance 
sounds ranging from violins to 'space age'. Over the next couple of hours, a series of humorous and musical interchanges between lead performers and guests took place to the accompaniment of the orchestra.

In the meantime, 15 teenage boys, distinguishable not only by their age but also their pink body shirts and white ties, served a threecourse meal at the tables set in rows before the men. The boys periodically returned to the tables to provide refills of tea and to clear up, carrying out these duties with quintessentially polite Javanese gestures of deference, dragging their right hands low to the ground upon passing their elders, and speaking only to be of assistance. By ten-thirty pm however, their duties completed, half a dozen of the young staff suddenly tore off their shirts and ties, kicked off their shoes and, in white undershirts, black formal pants and bare feet, began other world dancing (joged) around each other. Continuing to hop about and sweep their arms, the boys slowly swarmed toward and then onto the performance clearing. A few of them shouted repeatedly for dangdut songs, launching into ever more ecstatic dancing upon the fulfilment of their requests. The more the musicians complied, the further the catering group overtook the performance clearing. When a few of the teenage boys began circling the young female singer however, the village head and his colleague, who up to this point had been watching from a distance, ran into their path and herded them to an enclosure behind the guests. From there the young caterers continued to shout for more dangdut songs while dancing merrily among themselves.

Entertainment at this village circumcision reception, attended exclusively by men, became an occasion to mark transitions between youth and adulthood, campursari and dangdut musical genres, and other world and sexualised physicalities. The young staff members were able to challenge their marginal status through dance, a phenomenon Cowan (1990:185-6) also notes in relation to dance in rural Greece. However, here the youth overstepped their limits by invading the female performers' space, and with sexualisation overtaking other worlds, the authorities were compelled to step in and steer them away.

Performances around city kampung also became arenas for the playing out of tensions and accommodations between campursari and highly sexualised dangdut. At one Independence Day performance, the campursari singers' refined dress and subdued mannerisms contrasted sharply with the denim street wear and erotic dance moves of the guest dangdut singers who followed. The first dangdut singer, a denim-clad woman in her early twenties, broke into a song. Aided by the swooping trumpet sounds on keyboard and insistent 
drums from the orchestra, she interspersed hoots and wails with her singing. Along with her increasingly erotic movements, these roused large and surprisingly diverse segments of the audience. Another young woman sang 'Terlena', with her air of cute vulnerability in the introduction leading into brash and explicitly sexual dance routines. Some among the seated families appeared uninterested or mildly offended by this, but many more became animated with laughter, hand clapping, and rib poking.

To the extent that musical genres can be linked to their broader cultural associations, these kampung examples indicate that westernism was not prominent; the polite, Javanist engagements between performers and audience took place earlier in the evening; and heightened sexuality later in the events was the product of a conglomeration of nationalist, melayu, Indian and Arabic influences. While campursari and dangdut were central to contests around permissible sexuality at evening kampung performances, rock music in these settings was only likely to invoke other world and/or sexualised dancing if injected into, for example, the repertoire of a dangdut group. More often, rock music here was a vehicle for the expression of urban alienation and/or teen angst. Kampung rock physicalisations were akin to the immersed yet physically immobile audience receptions characteristic of Kridosono events dominated by teenage males.

Live rock music at kampung events was most often an early segment in a several act show, and the performers were typically male teenagers. For Independence Day in one city kampung, the first two acts were groups of teenage boys playing two songs each, all of which were versions of Indonesian alternative pop groups such as Padi and Dewa. Their raw and distorted renditions added an air of urban alienation to the original versions. A variation on this occurred with the Malioboro Arts Community at the Pajeksan kampung south of Sosrowijayan. Independence Day here featured 12 western-style rock bands playing music ranging from teenage 'hip-metal' to older generation pop (1950s and 1960s Beatlesque). The headline act was KPJM, who performed extended versions of their locally renowned jalanan songs. Here the audience applauded often and enthusiastically, but head nodding was the closest they came to dancing, and the large space before the stage remained empty.

The final event to be discussed in this section took place in Kusuman kampung, and warrants more extensive description. Musically, this performance combined campursari and dangdut with rock and soul music, and the different forms of physicalisation detachment engagement, other worlds and sexualisation - were 
clearly demarcated in space. Kusuman was more socially and ethnically uniform than Sosrowijayan, but it also housed a number of Sosrowijayan-based street workers and is only ten minutes by bicycle from Malioboro Street. The performance also involved members of the Tombo Sutris campursari orchestra (discussed later), as well as Yayi, who specialised in highly sexualised performances in a number of different settings.

The performance took place as part of the selapanan celebration that occurs 35 days after the birth of a child, one of many lifecycle rituals practiced in Java (Geertz 1960:38-50). When I arrived at nine $\mathrm{pm}$, the event was already underway. In addition to those formally invited, anybody living in the kampung could attend, with the result that by mid-evening attendance had reached over 200 people. These included both males and females of all age groups, and dressed with varying degrees of formality. While there were no formal demarcations, the guests nonetheless settled into distinct areas: the relatives and closest associates of Visnu and his wife enjoyed an elevated view midway back from the stage; a number of women, including those with older children, stood behind this row; most of Visnu's male friends crowded to the left of the stage; and a group of young mothers and their children sat directly in front of it. Most others stood or sat outwards from these circles, broadly reflecting their social distance from the hosts. Most physically distant but audibly dominant was a group of mostly young men dancing in a clearing over a waist-high wire fence five metres to the right of the band.

The 12 member group took up much of the large stage, with a narrow section at the front reserved for the lead performers. The players' wide range of musical skills enabled them to respond to audience requests and to the performances of the numerous local girls who got up to sing. These factors also became the basis for the group's improvisatory and/or comical passages. Musical styles shifted from campursari to combinations of campursari, dangdut, western rock, and soul.

Yayi, the 17 year-old professional singer discussed earlier, was the lead performer. Well experienced in the art of rousing yet containing an audience, each time she re-emerged to sing a few songs the atmosphere became more sexually charged, and yet she was also able to utilise her sexuality to steer audience behaviours. At ten o'clock she appeared wearing a skimpy lace top and jeans. However, seeing that the raucousness among the men dancing in the side enclosure was getting out of hand, she instructed the band to keep the tempo up but, with the air of having won the dancing men's consent, changed the theme to 'rock and roll'. She sang 
James Brown's 'I feel good', with orchestral accompaniment combining rhythmic precision with comical syncopations. The men to the side continued to dance but now with less gusto and bravado. ${ }^{2}$

Near the end of the show, people increasingly called on a number of teenage kampung girls to perform on stage. I found it difficult to determine whether the girls were enthusiastic about performing, or whether they were coerced into it. Their initial responses were gestures of unwillingness - arms folded and turning slightly away from the stage - although some men insisted that they were ' malu-malu kucing' (feigning shyness). In any event, when the girls performed, always in groups of two, the most vocally insistent in the audience urged them to display their sexuality as erotically as possible, especially in the instrumental passages. As I had seen at other kampung performances, most of the girls corkscrewed slowly to the ground and back up in an especially sexual manner. Physical responses from the audience varied. The men dancing in the side area hooted toward the stage, then returned to face each other and swing their arms ever higher into the air. Much like at the Purawisata events to be discussed next, the men's dancing combined other world mythical styles with a sexual charge. Most audience members at the Kusuman performance, including the hosts, did not seem offended or uncomfortable, appearing rather to treat the display of young female sexuality as a normal part of such festivities.

Musical physicalisations at this Kusuman event highlight patterns of spatial segregation and musical/genre divisions. Attendants were more or less segregated according to gender, age, and social proximity to the hosts. As the evening progressed, other worlds and sexual movements increased, the former prominently among the men dancing in a separate enclosure, the latter among female lead performers. Given the high volume and cramped conditions, simply being at the event meant engaging physically with it. Only the mothers of young children seated before the stage were able to stay relatively detached from the rest of the crowd. The other world moves of the men to the side were on the verge of becoming sexualised and dominating proceedings, as they did at the village ceremony discussed earlier, but here they were successfully contained. In part this was because the organizers had assigned them a separate area, but it was also due to Yayi and the orchestra's deft crowd management.

Are these overt displays of sexuality evidence of female autonomy, or of gender oppression? They can be seen as oppressed to the

2 The unwieldy behaviours of the adult males at this kampung event are of course but one of the great myriad of shifting 'masculine' cultural expressions found in Indonesia (Clark 2010). 
extent that they were objectified and given attention largely for their ability to display sexual allure. This position is further supported by the fact that the audience called for sexual displays only from teenage girls and not, for example, women in their twenties or thirties. On the other hand, Yayi in particular was able to direct guest behaviours even more effectively than the adult male MCs, providing a positive role model for the younger girls. ${ }^{3}$ Moreover, older women, including Visnu's mother, encouraged the girls' sexualised roles.

The music on this occasion did not fit into distinct genre categories. This was in part a result of the equipment available, but also of deliberate choice. Rather than presenting music with specific and distinct cultural associations - campursari: village-Javanism; dangdut: nationalism, and South and Central Asia-bound quasi-Islamic internationalism; rock: US and UK westernism; and soul: AfricanAmericanism - the music ranged across and between these. The refined/rough divide of 'high' and 'popular' art as described by Geertz (1960) is also difficult to maintain in this case. The relatively refined aspects of campursari were interwoven with the more salacious dangdut, with gamelan gongs featured in otherwise standard dangdut songs; campursari songs were given dangdut and rock flavours, for example with funk-style bass.

Nor was sexualisation confined to the performance of dangdut. 'Kuda lumping', a Javanese folk song with an 'other world' title referring to the toy horse used in jatilan, encouraged sexualisation on stage, while Yayi used the music of James Brown to curb sexualisation among the off-stage dancing men. In these ways, performers were able to deploy a variety of musical and cultural associations to steer the general behaviour and mood of the event in particular directions. The final section of this chapter returns again to Yogyakarta's entertainment venues. These cases will demonstrate a narrower scope for experimentation between genres and physical engagements and, consequently, different prospects for habitus plasticity.

\section{DANGDUT SHOWS AND PUB ROCK}

Two venues in Yogyakarta were unusual public spaces in that both centred on women dancing in highly sexualised ways. The first, Taman Ria, had clearly defined spatial separations between the female performers and the predominantly lower-class male Muslim audience. The second, Bar Borobudur, had porous spatial bound-

3 On creative dimensions of on-stage female dangdut performance, see Bader 2011. 
aries, attracted a mixed clientele including foreigners, and as a result generated and maintained contrasting gender relations.

Taman Ria at the Purawisata venue revolved around highly sexualised female dangdut singers performing on stage. Located on busy Bridjen Katamso Road outside the eastern walls of the Greater Kraton, Purawisata was a multi-function amusement park and cultural arts centre. Dangdut performances had been taking place there from nine pm through to one am virtually every night of the year over the past 12 years, meaning that tens of thousands of spectators and hundreds of lead performers had participated. We can therefore expect dangdut performances at Taman Ria to reveal significant patterns of behaviour in relation to musical sexualisation in Yogyakarta's commercial venues. During my research, dangdut singer/performers at the venue defied government and Muslim group bans on dressing and dancing in an overtly sexual manner. Their dresses had either long splits up to the hip, or were mini/seethrough combinations, and their slow simulations of sexual intercourse always induced mild frenzy among the men below them.

At the album launch event for a young star named Vivin, the audience was dressed especially tidily. While as usual the majority of the audience were young men of around 18 years of age, there was a slightly greater proportion of women in the audience than on average nights. Dancing was widespread through the audience, mostly comprising men dancing in couples. Despite being the occasion for an official album launch, the audience persistently shouted for evergreens like 'Terlena', 'Rindu' and 'Malam terakhir'. The singers and the band for Vivin's show were markedly more professional than on standard evenings. A new singer - there were over 15 in total - would emerge for each song in glamorous dress and makeup and evidently adept at sexualising her performance. Vivin engaged in a running commentary throughout and, as with Yayi in other settings, both roused and controlled the audience at the same time. Although from Jakarta, the singers spoke using polite forms of Javanese to keep the audience onside. They sang from a pre-planned repertoire, but also accepted requests from the audience, responding to bouts of excited shouting with calming phrases like 'What is it, darling?' (Apa, sayang?). During instrumental passages, they reminded the men to smile as they danced. The show began at ten pm and finished promptly at midnight, at which time the audience dispersed in an orderly fashion.

Bar Borobudur near Sosrowijayan differed from Taman Ria in many ways: it was a ranch-style bar featuring loud live rock music, high levels of alcohol consumption, and a distinct variation of musical sexualisation. Through much of the 1990s, the bar was a 
popular meeting and drinking spot for expatriates, travellers, and educators, along with a large number of Indonesians. By 2001, an increase in the number of sex workers and an overall decline in diversity of clientele had given the venue a seedy edge. The clientele generally numbered between ten and 80, depending mostly on the popularity of the band. Some customers stayed only a short while, but many would stay on at the bar until the closing time at one-thirty am, some then moving on to Prada eatery.

Physical movements at the bar were linked with alcohol, a relatively diverse clientele, and loud rock-oriented music, all of which influenced each other. Live bands sometimes transformed the venue into a crowded dance floor with sweaty singles and couples dancing, some becoming highly sexualised, that spilled over into the seating area. Perek clearly pursued money and/or a partner at Bar Borobudur, although it was also evident that they sometimes danced for their own pleasure. Perek and others especially enjoyed the Alaska Band, whose cover versions of Robbie Williams' 'Better man', a song by the world beat, Benin-born female singer Angelique Kidjo, and an extended, funk version of 'I will survive', stressed agency and personal responsibility. On the other hand, no one at Bar Borobudur played dangdut-style music.

Despite the many rough, even exploitative, aspects of Bar Borobudur, it remained one of very few inner-city venues conducive to after hours, mixed-gender, intercultural socialising. Bar Borobudur was to most kafe nightclubs and hotel bars what Opposite Resto was to the TransWeb hangout discussed earlier. In other words, both Bar Borobudur and Opposite Resto could become somewhat volatile; and yet, unlike during the Soeharto era, people here openly aired their opinions on social and political matters in ways that seemed at least as often socially bonding as tension inducing. Additionally, the regulars at the bar were more diverse than they may have at first appeared. For example, sex worker Lia had a penchant for Swedish and Greek folk musics, as well as the music and philosophy of Islamic culturalist Emma Ainun Nadjib (discussed later). And many of the apparent 'outsiders' at the bar were actually on familiar terms with influential Malioboro Street figures.

The perek at times seemed to revel in sexual exhibition, and many of them enjoyed the material spoils offered by foreigners such as all-expenses-paid journeys, jewellery, and fine clothing. However, in the longer term their situation is more complicated, with the success rate of such relationships being quite low (Dahles and Bras 1999:285). The sexualised behaviours of perek at Bar Borobudur were by no means separate from their daily interactions around Sosrowijayan. Unlike the male newcomer street guides, who could 
fraternise with foreigners and both bring in money and earn credibility with the Sosro Boys, any financially-based kudos that the perek could potentially gain through their attention grabbing clothing and mannerisms was offset both by this ruthless and often harsh form of commerce, as well as by kampung disapproval.

By contrast, at Purawisata's Taman Ria the highly sexualised dancing of the female dangdut singers was professional and separate from the audience, who were generally happy to dance among themselves. There were virtually no women in the audience. The lead performers combined their bodily displays with leadership and a command over the audience below. Perek at Bar Borobudur instead mixed with the clientele in their pursuit of money, and often danced around the customer tables in overtly sexual ways. 


\section{Conclusion}

In Part Two, I have classified music performances that took place in Yogyakarta's kampung and commercial entertainment venues according to detachment engagement, other worlds and sexualisation forms of musical physicalisation. Musical performance created arenas in which gender and other aspects of identity were negotiated, maintained, celebrated and/or contested in these venues, and by extension in Sosrowijayan. Among the kampung events discussed, wedding receptions were characterised by musically detached guests and hosts, regardless of class position. Physical engagement with music was greater at kampung events premised on other themes. On these occasions, inter-group animation generally reached its peak in the middle segment of the evening, as did transitions between generational groups and their favoured musical genres. Often an intermediary period of dangdut-related music and performance briefly enlivened the proceedings. Few young women and perek attended the kampung parties I witnessed, but some of the older, established women played leading roles at them.

Gendered behaviours in high-class hotels were broadly consistent with arguments that equate physical immobility with the expression of power in Java. Nonetheless, female staff, performers, and perek in these settings sometimes mobilised their physicality to enhance their positions in such high-stakes environments, characterised as they were by great economic disparities and a musically detached clientele. Performing work was generally insecure and unreliable. Nonetheless, performers' engaged and animated roles sometimes generated interactions, and arguably a kind of habitus plasticity, that were denied both general staff and perek. In the more middle-class kafe nightclub scene, spaces opened up for performers and clientele to mix across genders and outside kampung and other more traditional contexts. With the exception of Yogya Kafe however, music at kafe was not a central focus to the same extent as at Kridosono sports hall.

Other world jatilan events seemed to soothe gender tensions rather than intensify them. However, these kampung events differed from those at Kridosono in two main ways. Firstly, a broader audience attended jatilan, in generational and to an 
extent class terms; and second, audience/performer lines generally remained separate, both spatially and in terms of other world bodily movements. Another variant of other worlds physicalisation, distinct to both jatilan and the metal and electronic scenes, involved male audience members in kampung dancing in a joged style that to varying degrees merged with sexualisation. Other world commercial-venue events involving metal or electronic music displayed some class and inter-generational restrictions on involvement, but at the same time dance and performance here were markedly unconstrained by gender division and sexual tension. Other world commercial events therefore to various degrees challenged and transcended both conservative and sexualised gender roles.

Finally, variety and degrees of musical sexualisation are noteworthy in relation to questions of gender, habitus and autonomy in Yogyakarta. In some of the kampung musical events discussed above, participants contested and merged sexualisation with the other physicalisations. These interplays influenced and were influenced by shifts in musical genre. Loud live rock music at kampung events rarely resulted in high levels of physical movement while, by contrast, campursari/dangdut hybrid music often brought out intergenerational tension over acceptable or appropriate displays of public sexuality. These were occasions for other world dancing on the part of the men offstage, and onstage sexualisation on the part of lead female performers. Young men often fuelled this drive toward dangdut sexualisation, but so too did others. At the Kusuman event, much of the audience called for teenage girls to sing and dance on stage with overt sexuality. While this may have served to reinforce the sexually objectified role of women, Yayi's performance techniques suggest that processes of individual empowerment, as well as the generation of in-group solidarity among teenage girls, were also at work.

Purawisata centred on quasi-Islamic, lower-class versions of dang$d u t$, whereas Bar Borobudur was heavily westernised, in both music and clientele. At both establishments, men variously introduced other worldly behaviours into a sexualised environment, through mythic-style dancing and alcohol consumption respectively. The forms of female musical sexualisation differed across the venues. At Purawisata, women performed in a sexual manner from the safety of a separate stage. At Bar Borobudur by contrast, perek mixed with clientele; they often spent time there, and in Sosrowijayan generally. Perek were emblematic of women in the nocturnal world of music, alcohol consumption, western influence, and sexual objectification. 
The manifestations of detachment engagement, other worlds and sexualisation explored above suggest that music played a role in shaping neighbourhood gender relations far beyond that of merely producing temporary ruptures to everyday life. Kampung events involving music take much planning and preparation, making such events the enactment of 'social drama' (Turner 1982). The young women and men involved were at important developmental and social stages in their lives. Many teenage girls were compelled to perform in a sexual manner at kampung events and to be married and have children by the age of 25 . Through such ventures, women in particular risked social isolation by overstepping the bounds of acceptable kampung behaviour (Sullivan 1994), as had occurred to some of the older perek and street guides. However, some young women would branch out into different social situations, interacting with people whose class, ethnic and national backgrounds were different from their own, thereby providing material with which to reflect on and rethink any kampung-based dimensions of their habituated behaviours and roles.

Throughout Part Two I have discussed variants of musical genre and physicalisation in kampung and commercial-venue events. I reflected on intergenerational, class and other factors that intermingled with gendered aspects of the events, and of social life in Sosrowijayan and Yogyakarta more broadly. Having now addressed capital conversions around street music and gendered physicalities at kampung and commercial-venue events, Part Three completes the study by applying the notions of bureaucratic field and grounded cosmopolitanism to musical performances in Yogyakarta's state institutions, noting in particular campursari/village, jalanan/city and related musical associations and their relationship to issues of state power and intergroup relations in the early postSoeharto era. 